УДК 378.016:811.161.2:004

Греб Марія Михайлівна

доктор педагогічних наук, доцент, завідувачка кафедри української мови та славістики, Бердянський державний педагогічний університет, м. Бердянськ, Україна

ORCID ID 0000-0003-2874-7985

marygreb@i.ua

Грона Наталія Вікторівна

доктор педагогічних наук, викладачка вищої категорії, викладачка-методистка, голова циклової комісії викладачів української мови і літератури

Прилуцький гуманітарно-педагогічний коледж ім. І.Я. Франка, м. Прилуки, Україна

ORCID ID 0000-0003-2578-2865

natashagrona@ukr.net

\title{
ІНФОРМАЦІЙНО-КОМУНІКАЦІЙНІ ТЕХНОЛОГІЇ ЯК ЗАСІБ ФОРМУВАННЯ ЛІНГВОДИДАКТИЧНОЇ КОМПЕТЕНТНОСТІ МАЙБУТНІХ УЧИТЕЛІВ ПОЧАТКОВИХ КЛАСІВ
}

\begin{abstract}
Анотація. У статті досліджено специфіку застосування інформаційно-комунікаційних технологій у процесі формування лінгводидактичної компетентності майбутніх учителів початкових класів. Теоретично обгрунтовано та показано на конкретних прикладах ефективність формування лінгводидактичної компетентності майбутніх учителів початкових класів засобами інформаційно-комунікаційних технологій. Автори доводять, що застосування IКТ покращує сприйняття, осмислення й запам'ятовування навчальної інформації, допомагає здійснити диференційований підхід до навчання студентів і позитивно впливає на їх мотивацію до навчальної діяльності.

Проаналізовано зміст лінгводидактичної підготовки майбутнього вчителя початкових класів, яка пов’язана $з$ фаховою поліфункційністю, багатопредметністю, розгалуженістю художньо-творчої й емоційно-комунікативної сфери взаємодії з учнями, високим рівнем діалогічності й референтності в стосунках із ними, духовно-моральною насиченістю змісту освіти.

Акцентовано на тому, що досягнення в лінгвістиці впливають не тільки на зміст навчання мови, а й на прийоми роботи, види вправ, дидактичний матеріал тощо. Це зумовлює постійне оновлення системи лінгводидактичної підготовки студентів у вищій школі відповідно до інноваційних аспектів розвитку освітнього простору, удосконалює умови створення, збереження та забезпечення оптимальних способів представлення інформації засобами інформаційно-комунікаційних технологій.

Сформульовано рекомендації майбутнім фахівцям для створення презентацій. Здійснено аналіз упровадження та використання комп'ютерних тестів (у комп'ютерній програмі тестування ASSIST-II (Асистент-II). Така форма, як правило, викликає додатковий інтерес у студентів, а крім того, дає змогу їм самостійно перевірити та оцінити рівень власних знань 3 конкретної теми (модуля).

Описано технологію майндмеппінгу, яка заснована на зображенні асоціативних зв’язків (складання ментальних карт: карт пам'яті, інтелект-карт, карт розуму, карт мислення) для поєднання візуалізації навчального матеріалу з його «стисненням».

Проаналізовано можливості та переваги кожної ІКТ під час формування лінгводидактичної компетентності майбутнього вчителя початкових класів.
\end{abstract}

Ключові слова: лінгводидактична компетентність; учитель початкових класів; інформаційно-комунікаційні технології; презентація; комп'ютерне тестування; мобільні додатки; технологія майндмеппінгу.

\section{1. ВСТУП}

Постановка проблеми. Спрямування соціально-економічного розвитку України на європейські стандарти передбачає якісне оновлення освіти. Основним напрямом у 
закладах вищої освіти стає підготовка фахівців, які готові навчати, розвивати i виховувати громадянина України, уміють швидко й креативно розв'язувати проблеми професійного та особистісного характеру, прагнуть позитивних змін у житті країни. Важливим чинником розвитку освітнього простору й засобом удосконалення умов здобуття знань є інформаційно-комунікаційні технології, спрямовані на створення, збереження та забезпечення оптимальних способів представлення інформації. Наявність таких технологій актуалізує проблему підготовки майбутніх фахівців для початкової школи, здатних ефективно вирішувати професійні завдання, а також зумовлює постійне оновлення системи лінгводидактичної підготовки студентів у вищій школі відповідно до інноваційних аспектів парадигми освіти XXI століття.

Сучасні тенденції розвитку освіти інтегрують напрями традиційного та інноваційного навчання. Традиційна освіта передбачає передачу майбутнім фахівцям знань і досвіду для використання в подальшій професійній діяльності. Інноваційна освіта зорієнтована на продуктивний діалог і співробітництво учасників освітнього процесу з урахуванням змін у характері суспільних вимог до особистості.

Мотивація до продуктивної, творчої професійної діяльності забезпечує підготовку висококваліфікованого вчителя початкових класів. У цьому аспекті інформаційно-комунікаційні технології (ІКТ) стають вагомим засобом навчальнопізнавальної та науково-дослідної діяльності студентської молоді. При пошуку ефективних шляхів підготовки майбутнього фахівця увага зосереджується на активному впровадженні в освітній процес закладів вищої освіти інформаційнокомунікаційних технологій.

Застосування IКT покращує сприйняття, осмислення й запам'ятовування навчальної інформації, здійснює диференційований підхід до студентів і позитивно впливає на їх мотивацію до навчальної діяльності.

Проблему використання ІКТ в освітньому процесі досліджують М.Жалдак, Е.Машбіц, Н.Морзе, Н.Тализіна, В. Шолохович та ін. Вивчення проблеми використання ІКТ у професійній підготовці майбутніх учителів початкових класів має нечисленну бібліографію (М.Левшин, Д.Мазоха, Л.Петухова, І.Шапошнікова, О.Шиман). Водночас 3-поміж значної кількості наукових праць із застосування ІКТ немає робіт, у яких розглядається проблема підготовки вчителів початкових класів до професійної діяльності в контексті формування лінгводидактичної компетентності.

Професійна підготовка майбутнього фахівця в наукових працях розглядається як системне утворення, для якого характерними є: функціональність, упорядкованість, організованість, динамічність та готовність до саморозвитку. Випускники закладів вищої освіти повинні мати змогу займати активну позицію у сфері інформаційної взаємодії і бути затребуваними фахівцями в суспільстві.

Доцільність дослідження визначаємо і з огляду на об'єктивну необхідність у розв'язанні суперечностей між: вимогами модернізації сучасної освіти на інноваційних засадах та недостатнім рівнем готовності вчителів початкових класів до розв'язання цієї проблеми; формалізованим підходом до створення власних мультимедійних дидактичних матеріалів студентами під час вивчення методики навчання української мови та відсутністю в них досвіду продукування або добору й комбінування існуючих IКТ; між сформованими компетентностями, знаннями та вміннями, визначеними профстандартом учителя початкових класів Нової української школи (НУШ) i здатністю вітчизняних вишів підготувати студента відповідно до цих вимог; потенційними можливостями сучасних лінгводидактичних технологій у підготовці майбутнього фахівця до навчання української мови учнів початкових класів i недостатнім упровадженням їх в освітній процес вишу. 
Досвід доводить, що застосування IКT у підготовці майбутніх учителів початкової школи позитивно впливає на результат навчання. У ключовому проєкті Концепції «Нова українська школа» виокремлено такі основні вектори розвитку: інтегрованість змісту освіти на основі ключових компетентностей, потрібних для успішної самореалізації в суспільстві, упровадження інноваційних методик навчання, умотивований учитель, який має свободу творчості й розвивається професійно, педагогіка партнерства учня і вчителя, наскрізний процес виховання, який формує цінності; децентралізація як ефективне управління, що надасть школі реальну автономію, сучасне освітнє середовище, яке грунтується на IКТ [1, с. 10]. В основі Концепції НУШ - перехід від школи знань до школи компетентностей.

Концепція реалізації державної політики у сфері реформування загальної середньої освіти розглядає інформаційно-комунікаційні технології в освітньому процесі як «інструмент забезпечення успіху» розвитку Нової української школи. Серед десяти ключових компетентностей, які мають набути діти під час вивчення різних предметів на всіх етапах освіти, $\epsilon$ інформаційно-цифрова компетентність, що «передбачає впевнене, і водночас критичне застосування інформаційно-комунікаційних технологій для створення, пошуку, обробки, обміну інформацією на роботі, у публічному просторі та приватному спілкуванні» [1, с. 16]. Вона передбачає інформаційну й медіаграмотність, знання основ програмування, розвиток алгоритмічного мислення, уміння працювати з базами даних, навички безпечної роботи в Інтернеті та володіння засобами кібербезпеки, розуміння етики роботи 3 інформацією (авторське право, інтелектуальна власність тощо) [1, с. 16]. Тому оволодіння IКТ майбутніми вчителями початкових класів формує здатність орієнтуватись в інформаційному просторі, оперувати даними на основі використання сучасних IКТ для ефективного виконання професійних обов'язків, реалізації компетентнісного змісту навчання.

У зв'язку з необхідністю вирішення проблеми інтенсифікації й індивідуалізації пізнавальної діяльності студентів, швидким оновленням наукової інформації, яку необхідно встигнути передати майбутнім фахівцям у процесі навчання, часовою обмеженістю аудиторних занять виникає потреба в упровадженні IКТ в освітній процес. Це мотивує студентів на творчу роботу з урахуванням індивідуальних здібностей, інтересів і потреб, забезпечує критичний аналіз відомостей та даних, отриманих із різних джерел за допомогою ІКТ.

Аналіз останніх досліджень і публікацій. Ретроспективний аналіз досліджень українських і зарубіжних науковців переконав, що проблемі застосування IКТ в освітньому процесі присвячено низку праць, зокрема методичним аспектам інформатизації освіти (О. Буйницька [2], В. Биков [3], А. Верлань, М. Жалдак, Н. Морзе, Ю. Рамський, Ю. Триус, О. Щербак), мультимедійним технологіям в освітньому процесі (Н. Голівер, О. Іщенко [4], Н. Іщук, О Комар [5], О. Копусь [6], В. Поляков [7], С. Хоменко [8], Л. Шевченко, С. Яцюк); розробленню методичних основ проєктування, створення і використання мультимедійних навчальних програм та мультимедійних навчальних комплексів (Г. Асвацатуров, Р. Адамов, В. Афанасьєв, Т. Бабенко, О. Гаєвський, А. Горшков, С. Дмитрієв, В. Підгорна, О. Пінчук, А. Старкова, В. Таргонська, С. Трапезникова та ін.); психолого-педагогічним i технічним аспектам застосування мультимедійних технологій (Е. Полат, М. Фролов, С. Христочевський та ін.); використанню комп'ютера на уроках у початкових класах (Г. Асвацатуров, Ю. Громова, І. Мураль, О. Пінчук, Л. Чемоніна, Л. Югова та ін.).

Сучасні дослідники визначають, що підготовка майбутніх фахівців засобами IКТ припускає надзвичайно широкий спектр інформаційних знань і вмінь, які полегшують вивчення лінгводидактичних теоретико-методичних засад. В. Поляков визначає інформатичну підготовку як процес, спрямований на засвоєння знань та формування 
навичок з питань застосування ІКТ у подальшій професійній діяльності. Головним завданням інформатичної підготовки студентів учений називає забезпечення майбутнього спеціаліста грунтовними теоретичними знаннями, уміннями та навичками у сфері інформатики та IКТ [7, с. 115].

С. Хоменко вважає, що ІКТ застосовуються в якості допоміжного засобу для ефективного вирішення дидактичних завдань[8, с. 24].

О. Іщенко визначає можливості ІКТ як засобу, що моделює зміст навчальних об'єктів шляхом конструювання [4, с. 10].

О. Буйницька зауважує, що впровадження ІКТ у навчання студентів активізує розвиток внутрішніх мотивів і вмінь здобувати й оновлювати знання, збагачувати досвід інноваційними технологіями, використовувати комп'ютерну техніку для пошуку і використання інформації, оволодіння навичками самостійної роботи в освітньому процесі [2, с. 42].

Ми поділяємо позицію В. Бикова, що «на основі поєднання традиційних педагогічних та інформаційно-комунікаційних технологій навчання вдається значно ефективніше розвинути й примножити природні задатки та здібності людини. Використання цих технологій у процесі навчання створює додаткові умови й спричинює появу нових цілей та оновлення змісту освіти, дає змогу досягти значно більших результатів навчальної діяльності, забезпечити для кожного іiі учасника формування й розвиток власної освітньої траєкторії» [3, с. 13]. Тому студентів потрібно не тільки навчити використовувати ІКТ з конкретною навчальною метою, а дати їм сукупність знань, умінь і навичок, які забезпечать самостійне набуття компетентностей, що відповідають сучасному рівню розвитку процесу інформатизації освіти.

Аналіз наукових розвідок дає підстави стверджувати, що проблема теоретикометодологічних особливостей використання IКТ у професійній підготовці майбутніх учителів початкових класів є малодослідженою. Це наукові розвідки М.Левшина, Д.Мазохи, Л.Петухової, І. Шапошнікової, О.Шиман.

Проблемі формування інформаційної компетентності вчителів присвячені роботи зарубіжних науковців, зокрема Т. Бернерс-Лі (Tim Berners-Lee), O. Кемпісато (Oswald Campesato), К. Нільсона (Kevin Nilson), Т. O'Рейллі (O'Reilly, Tim), Д. Xapica (Daniel Harris). Серед фундаментальних досліджень використання IКТ для вчителів слід виділити позицію В. Браздейкіса, який тлумачить інформаційну компетентність педагога як знання, уміння, ставлення, цінності, а також індивідуальні риси особистості, що дають ій можливість успішно вирисовувати ІКТ в освітній діяльності [9]. Дослідник виділяє два рівні інформаційно-комунікаційної компетентності педагога: базову та інтегральну. Базова містить три компоненти: соціальний (знання етичних та юридичних норм застосування IКТ у закладах освіти та їх дотримання), інформаційний (практичне застосування інформаційних навичок 3 урахуванням особливостей викладання дисципліни) та технологічний (здатність безпосередньо використовувати IКТ).

Застосування ІКТ в освітньому процесі дає можливість оперативно добирати потрібний навчальний матеріал, розробляти нові навчальні плани та програми, формувати вміння аналізувати ефективність роботи та корегувати навчальний матеріал [10]. Відповідно до системи ISTE (International Society for Technology in Education) стандарт IКТ-компетентності для вчителів має чотири компоненти: технологічний, соціально-етичний, педагогічний та професійний [11].

Такий підхід дає можливість дійти висновку, що вчитель/викладач повинен не лише вміти користуватись технічними засобами, а також методично коректно використовувати ІКТ-ресурси, бути фахівцем у соціально-етичних питаннях (комп'ютерна безпека, плагіат, ліцензія програмного забезпечення, право 
інтелектуальної власності, недоторканості приватного життя, кіберетикет, використання апаратного i програмного забезпечення для студентів із особливими потребами тощо) [12, с. 114].

Володіння ІКТ забезпечує успішну реалізацію діяльнісного, особистісно орієнтованого та компетентнісного підходів. Компетентнісний підхід до підготовки учнів/студентів передбачає зміну результату освіти усталених знань, умінь та навичок, вияв компетенцій та набуття компетентності. Компетентності, на думку науковців, $є$ індикаторами, що визначають готовність до конкретної діяльності, сприяють особистому розвитку та продуктивній участі в житті суспільства[1; 5; 6]. Це дає можливість майбутньому фахівцеві орієнтуватись в умовах сучасного суспільства, інформаційному просторі, подальшому здобутті освіти, на ринку праці.

Отже, компетентнісний підхід зміщує акценти 3 процесу на результат освіти в діяльнісному вимірі, вимагає посиленої уваги до лінгвометодичної підготовки майбутнього фахівця як засобу формування лінгвометодичної компетентності.

Процесуальні складники компетентнісного підходу, розроблені в дослідженнях А. Асанової, Н. Бібік, Л. Ващенко, О. Горошкіної, І. Зимньої, О. Кучерук, О. Овчарук, О. Пометун, О. Савченко, О.Семеног, В. Лозової, М.Пентилюк, С. Сєрікова, О. Хуторського, слугують теоретичним підгрунтям для визначення лінгводидактичної компетентності майбутнього вчителя початкових класів як інтегрованої властивості особистості, у якій органічно поєднано мовно-комунікативні знання і вміння 3 грунтовною лінгвометодичною підготовкою, умінням втілювати інноваційні технології навчання мови.

Мета статті - визначення ефективних шляхів формування лінгводидактичної компетентності майбутніх учителів початкових класів засобами IКT.

Відповідно до мети визначено такі основні завдання дослідження:

1. Схарактеризувати зміст базових понять дослідження та особливості лінгводидактичної компетентності майбутніх учителів початкових класів засобами IKT.

2. Теоретично обгрунтувати організаційно-педагогічні умови застосування IКТ у процесі викладання сучасної української мови, методики навчання української мови.

3. Показати на конкретних прикладах ефективність формування лінгводидактичної компетентності майбутніх учителів початкових класів засобами IKT.

4. 3'ясувати дієвість застосування інформаційно-комунікаційних технологій у процесі лінгводидактичної підготовки майбутніх фахівців для початкової школи.

\section{2. РЕЗУЛЬТАТИ ДОСЛІДЖЕННЯ}

У процесі аналізу науково-методичної літератури ми з'ясували, що наявні різні дефініції освітнього феномену «лінгводидактична компетентність»: володіння випускником наборами знань, умінь, навичок та досвідом оцінного ставлення до предмета, змісту та структури мовознавчої дисципліни, використання принципів, методів, прийомів, засобів та форм навчання [13, с.16]; лінгводидактична компетентність учителя-словесника в складі його методичної компетентності [14, с. 4]; володіння майбутнім фахівцем сукупністю знань, умінь, навичок і досвідом оцінного ставлення до суб'єкта, об'єкта, предмета, змісту та структури мовознавчих i лінгводидактичних дисциплін, умінням реалізовувати принципи, методи, прийоми, засоби та форми навчання, що становлять інтегровану характеристику якості особистості майбутнього фахівця [6, с. 27]. 
У нашому дослідженні ми спираємось на визначення лінгводидактичної компетентності майбутнього вчителя початкових класів, запропоноване I. Хижняк: «здатність на високому науковому й методичному рівнях, з урахуванням психологічної та виховної специфіки, застосовуючи різноманітні форми організації навчальновиховного процесу та постійно самовдосконалюючись, якісно організовувати процес становлення в молодших школярів мовно-мовленнєвої компетентності» [13, с. 168].

У контексті сучасних вимог вагомого значення набуває проблема лінгводидактичної підготовки майбутнього вчителя початкових класів, оскільки його діяльність пов'язана 3 фаховою поліфункційністю, багатопредметністю, розгалуженістю художньо-творчої й емоційно-комунікативної сфери взаємодії 3 учнями, високим рівнем діалогічності й референтності в стосунках із ними, духовноморальною насиченістю змісту освіти.

Майбутні вчителі мають усвідомити, що лінгвістичну інформацію про закони сучасної української мови використовуємо в методиці викладання української мови як основоположну. Отже, якщо на окремому етапі розвитку науки змінюється вихідний лінгвістичний матеріал, то перебудовується вся лінгводидактична система. Досягнення в лінгвістиці впливають не тільки на зміст навчання мови, а й на прийоми роботи, види вправ, дидактичний матеріал тощо. Так, розвиток у мовознавстві таких напрямів, як-от теорія тексту (текстологія), функціональна стилістика, культура мови й мовлення, психолінгвістика, стали поштовхом для оновлення методичної системи навчання української мови в закладах вищої освіти [15].

3-поміж пріоритетних напрямів реформування вищої школи важливе місце посідають питання оновлення змісту лінгводидактичної підготовки - упровадження ефективних педагогічних технологій, створення нової системи методичного й інформаційного забезпечення освітнього процесу. Особливого значення для підвищення наукового рівня методичної підготовки майбутнього вчителя до навчання української мови в початковій школі набуває розвиток та поглиблення лінгводидактичних знань. Оволодіння лінгводидактичними засадами навчання рідної мови сприяє усвідомленню перспективних тенденцій та завдань шкільного курсу рідної мови й методичної науки загалом; допомагає орієнтуватись у нових концепціях, теоріях, ідеях, технологіях; озброює вчителя системою методів педагогічного дослідження; забезпечує добір ефективних методів, прийомів і форм організації процесу мовної освіти школярів; дає змогу моделювати методичні ситуації та аналізувати шляхи виходу з них.

Спираючись на дослідження В. Владимирової, у структурі лінгводидактичної компетентності ми виділяємо такі складники: особистісно-мотиваційний (навчальнопізнавальні мотиви; мотиви професійної діяльності; аксіологічні мотиви), знаннєвий (знання сутності i структури лінгводидактичної компетентності); знання термінологічного апарату; знання характеристики вправ і завдань 3 формування базових та метапредметних компетентностей; пізнавально-операційний (володіння лінгводидактичною термінологічною лексикою; уміння аналізувати, виконувати i складати вправи й завдання з формування базових і метапредметних компетентностей, а також фрагменти та плани-конспекти уроків з української мови у початковій школі; уміння використовувати прийоми зіставлення, порівняння, оцінювання (уміння адекватно оцінювати власні навчальні досягнення, а також здатність до самоаналізу та самовдосконалення) [17].

Результатом роботи викладача і студента 3 формування лінгводидактичної компетентності мають стати сформовані в майбутнього вчителя професійні вміння, які О. Кучерук умовно поділяє на три групи: загальнопедагогічні вміння, які пов'язані 3 самореалізацією у сфері педагогічної творчості, оригінальним моделюванням 
навчально-виховного процесу, творчим мисленням, нестандартним розв'язанням педагогічних ситуацій, проведенням і аналізом уроків, позакласних заходів; спеціальні, які випливають із специфіки курсу методики української мови, зокрема вміння працювати $з$ навчально-методичною літературою, аналізувати труднощі в засвоєнні учнями мови і добирати шляхи подолання їх, розробляти на основі власного фахового i особистісного досвіду інноваційні методи, технології навчання мови, складати систему мовно-мовленнєвих вправ і завдань, організовувати підготовку до переказів і творів, аналізувати текст з погляду функціонування в ньому мовних одиниць, проєктувати й проводити роботу над різними видами мовних помилок; комунікативні, пов'язані 3 культурою мовлення, технікою виразного мовлення, ефективністю i щирістю спілкування залежно від комунікативної педагогічної ситуації [18]. Сучасні підходи до формування цих умінь передбачають застосування IКТ. Оскільки, застарілі методи та засоби навчання не відповідають вимогам сучасного навчання i не підлягають тенденціям стрімкого розвитку науково-технічного прогресу, то це спонукає викладачів до впровадження інноваційних методів навчання та використання й адаптації ІКТ в освітньому процесі. Особливо ця проблема гостро постає під час формування професійних умінь i навичок, оскільки для ефективного їх засвоєння потрібно застосовувати значну кількість наочних матеріалів та інтерактивних засобів.

IКТ забезпечують та підтримують інформаційні процеси пошуку, збору, передачі, збереження, накопичення, тиражування інформації та процедури доступу до неї. Навчальні ІКТ повідомляють знання, формують уміння, навички навчальної діяльності. ІКТ-тренажери призначені для відпрацювання вмінь i навичок, повторення та закріплення пройденого матеріалу. Інформаційно-пошукові ІКТ знаходять інформацію, формують уміння й навички із систематизації інформації. Види сучасних IKT: комп `отерні технології на базі CD-ROM: текстові редактори; гіпертекстові редактори; редактори мультимедійних презентацій; інтернет-технології першого покоління: електронна пошта, форум, аудіо-, відеочат, засоби IP-телефонії, платформи для мережевих курсів; інтернет-технології другого покоління: блоги, сайти, мікроблоги, ВікіВікі, сервіси для зберігання фото, відео, презентацій, соціально-пошукові системи, контактні сервіси; види сучасних IКT: Smartтехнології, хмарні технології, WebSyndication, Second Life, геосервіси; технології Веб 3.0 (мобільні технологіï) [1, c. 15].

Застосування сучасних ІКТ у навчанні - одна 3 найбільш важливих і стійких тенденцій розвитку світового освітнього процесу. У вітчизняних навчальних закладах в останні роки засоби ІКТ стали все частіше використовувати під час вивчення більшості навчальних предметів [19, с. 205]. Застосування сучасних ІКТ у підготовці майбутнього вчителя початкових класів визначено як необхідну умову для забезпечення нової якості освіти, де основне місце відводиться професійній підготовці фахівців, яка виступає показником його конкурентоспроможності та передбачає наявність у свойй структурі лінгводидактичної компетентності.

Переваги використання IКТ можна звести до двох груп: технічних і дидактичних [21, с. 114]. Використання IКТ у роботі педагога дає можливість: самоосвіти, підвищення його професійного рівня; навчатися і здобувати знання, уміння та якості, необхідні сучасній людині; отримувати оперативно інформацію 3 теми, оновлювати навчальний та дидактичний матеріал; мати доступ до методичної бази розробок; спілкуватися 3 колегами на різних форумах; отримувати кваліфіковані консультації та поради експертів; публікувати свої матеріали; брати участь в обговоренні опублікованих матеріалів, у професійних конкурсах; обмінюватися досвідом з колегами 3 інших регіонів і країн [21, с. 128].

Ми провели анкетування серед майбутніх учителів початкових класів 3 метою 
визначення рівня обізнаності щодо використання ІКТ в освітній діяльності:

1. Як часто Ви користуєтесь мережею Інтернет з навчальною метою?

2. Назвіть ресурси, які ви використовуєте.

3. Чи достатньо для вас застосовувати лише комп'ютерні технології в навчанні?

4. Що, на вашу думку, належить до ІКТ?

5. Чи ефективне застосування ІКТ під час вивчення сучасної української мови, методики навчання української мови? Чому?

6. Чи використовуєте ви мобільні ІКТ в освітньому процесі (смартфони, планшети, міні-ПК)?

7. Назвіть програмні продукти, корисні для вивчення сучасної української мови, методики навчання української мови?

8. Що таке мобільне навчання? Як ви ставитесь до його застосування у вашій професійній підготовці?

9. Чи хотіли б ви вивчати ІКТ?

10. Чи будете ви застосовувати інформаційно-комунікаційні технології в подальшій професійній діяльності? Як саме?

Більшість опитаних (67\%) уважають доцільним використання IКТ під час професійної діяльності. Це дає можливість використовувати різні форми наочності, які впливають на ефективність організації й представлення теоретичного матеріалу у вигляді таблиць, схем, опорних конспектів тощо. З'являється можливість демонструвати не лише статичну інформацію, але й мовні явища в динаміці з використанням кольору, графіки, ефекту мерехтіння, звуку, піктографії, «оживлення» ілюстрацій та ін. А це якісно новий рівень застосування пояснювально-ілюстративного матеріалу та репродуктивних методів навчання.

Респонденти вважають, що однією $з$ переваг використання IКТ на заняттях із сучасної української мови, методики навчання української мови $\epsilon$ перехід від вербальних методів навчання на методи пошукової і творчої діяльності, що дає можливість кардинально оновити звичайні форми роботи учителя/викладача, сприяє цікавому й повнішому, усебічному розкриттю навіть дуже складного навчального матеріалу, сприяючи значному скороченню навчального часу для успішного засвоєння теми (модуля).

76 \% опитаних вважають, що мобільне навчання зменшує обмеження здобуття освіти за місцем проживання, дає можливість поєднати аудиторне й позааудиторне навчання, обмінюватися інформацією, ставити запитання і відпрацьовувати нові навички за межами освітнього закладу. Студенти починають коментувати, обговорювати або обмінюватися електронними даними, традиційна роль викладача як авторитету змінюється на більш сучасну роль співавтора або наставника.

Усі респонденти погоджуються використовувати IКТ у своїй роботі, адже впровадження IКТ у сучасний освітній простір суттєво прискорює передавання знань і накопиченого технологічного та соціального досвіду людства не тільки від покоління до покоління, а й від однієї людини до іншої. Сучасні ІКТ покращують якість навчання, дають змогу людині швидше адаптуватися в соціумі, самостійно одержувати необхідні знання в постіндустріальному суспільстві. Активне й ефективне впровадження цих технологій $є$ важливим чинником модернізації освітньої діяльності в контексті європейських вимог.

Серед програмних продуктів для вивчення сучасної української мови студенти виділили «Розум.org.ua. Швидкий доступ до знань» - збірка корисних словників: «100 видатних українців», «Антисуржик», «Неправильно-правильно», «Орфографічний словник української мови», «Російсько-український словник сталих виразів», «Словник іншомовних слів», «Словник синонімів». - для дітей середнього шкільного віку; 
«Словники України online» (http://lcorp.ulif.org.ua/dictua/) - онлайновий словник, розроблений українським мовно-інформаційним фондом Національної академії наук України, із словозміною, синонімією i фразеологією. Особливою популярністю користуються мобільні додатки, зокрема, добірка додатків для Android, які допомагають у вивченні й поглибленні знань з української мови. Наприклад «Р.І.Д.» - додаток, який розширює словниковий запас під час ознайомлення з власне українськими виразами у нетривіальній формі. Головна мета додатку - допомогти викорінити суржик із мови. Цей додаток допоможе не тільки збагатити лексикон, але і збільшити знання про історію українського народу, адже кожного дня на гаджет надсилаються аутентичні українські слова $з$ поясненням змісту. Після додавання до власного словника надісланих слів нараховуються спеціальні бали - піщинки часу. Отже, щоденно можна розширювати свій словниковий запас. Зібрані бали-піщинки можна обмінювати на пізнавальний контент у додатку «Скарбниця» за категоріями, що найбільш цікавлять - «Книги», «Постаті», «Події». Додаткові бали можна отримувати також за запропоновані слова. За кількістю внутрішньої «валюти» можна поступово досягати більш високого рівня з семи можливих, від «неофіту» до «володаря часу»; додаток «Mova», у якому за допомогою онлайн малюнків з дев'яти тем (антисуржик, пароніми, фразеологізми, орфографія, наголос тощо), учням без додаткових зусиль вдається опанувати найскладніші правила 3 різних розділів української мови: основні правила правопису, дізнатися, як позбутись кальок, замінюючи росіянізми власне українськими словами; учитися правильно наголошувати слова та добирати синоніми; запам'ятовувати типові фразеологізми тощо. Для вивчення методики української мови не розроблено жодного такого ресурсу, але на часі період змін і прогресивних ідей в освіті, тому такий продукт потребує створення.

Традиційно на заняттях ми вчимо майбутніх фахівців початкової школи створювати презентації з дотриманням відповідних вимог, використовуючи програму MS Office PowerPoint і спеціалізовані редактори: Macromedia Flash, Picasa, Photodex ProShow та ін. Зокрема програма Picasa (Google, Inc.) дає можливість легко виокремлювати статичні й динамічні зображення 3 Інтернету; зручно, швидко проєктувати як слайд-шоу, так і навчальні фільми; додавати до проєкту текстові й звукові коментарі; створювати колажі зі статичних зображень; з легкістю завантажувати зображення у вебальбоми тощо. Створені вебальбоми ми розміщуємо на університетському сервері та оцінюємо, застосовуємо відповідно до освітніх потреб. Студенти, готуючи презентацію, ураховують вимоги до змісту й оформлення слайдів: кожен слайд має відображати одну думку; текст має складатись 3 коротких слів та простих речень (6-8 рядків, загальна кількість слів не повинна перевищувати 50); дієслова мають бути в одній часовій формі; заголовки повинні привертати увагу аудиторії та узагальнювати основні ідеї слайда; у заголовках пишемо великі і малі літери (а не тільки великі); кількість блоків статистичних даних на одному слайді - не більше чотирьох; підпис до ілюстрації розмішуємо під нею, а не над нею; усі слайди презентації мають бути витримані в одному стилі; найбільш важливу інформацію розташовуємо в центрі слайда; наявність не більше одного логічного наголосу: яскравість, обведення, миготіння, рух; інформацію подаємо привабливо, оригінально; оптимальна кількість слайдів - 20-25. Наприклад, на рисунку 1 пропонуємо окремі слайди презентації до візитної картки проєкту «Чи престижно бути грамотним?». 

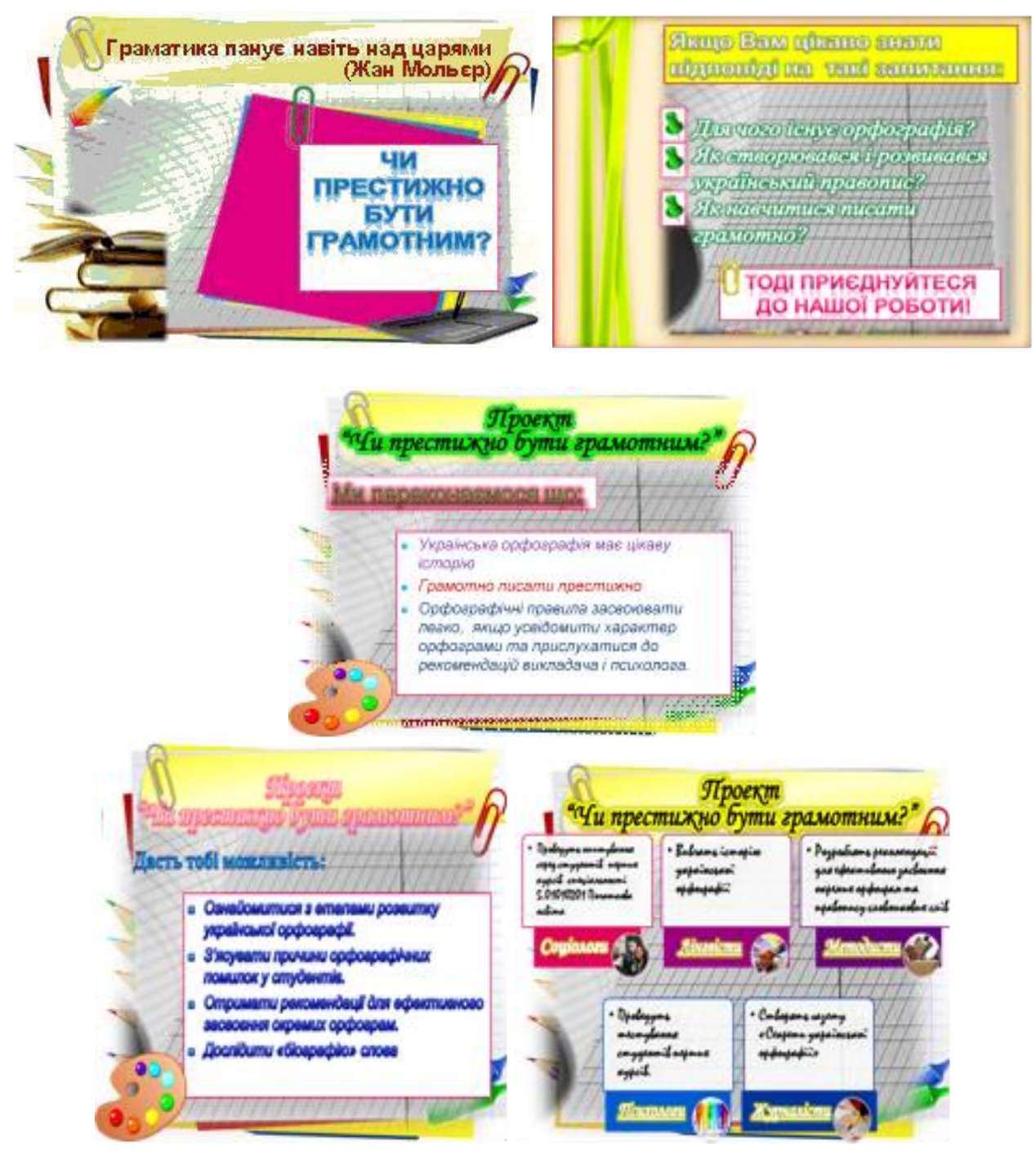

Рис. 1. Слайди презентації до візитної картки проєкту «Чи престижно бути грамотним?»

Систематичний контроль знань великої кількості студентів викликає необхідність автоматизації контролю, застосування комп'ютерної техніки і відповідного програмного забезпечення. У поєднанні з іншими видами перевірки використання тестових завдань 3 комп'ютерною підтримкою $є$ досить ефективним інструментом, що стимулює підготовку студентів до кожного заняття й підвищує мотивацію вивчення предмета. Усний контроль можна замінити комп'ютерним під час проведення підсумкових занять, контрольних робіт, іспитів тощо.

Упровадження та використання тестів забезпечує їхнє функціонування як в локальному комп'ютері, так і в локальній мережі навчальної лабораторії. Це, як правило, викликає додатковий інтерес у студентів, а крім того, дає змогу їм самостійно без участі викладача перевірити та оцінити рівень власних знань 3 конкретної теми (модуля). У комп'ютерній програмі тестування ASSIST-II (Асистент-II) використовується система реєстрації ходу перевірки та іï результатів, зокрема таких показників, як-от: час виконання тестового завдання, кількість помилкових i правильних відповідей, підсумкова оцінка.

Під час проведення моніторингу знань студентів з методики навчання української мови найбільш доцільно використовувати пакет комп'ютерних програм SunRav 
TestOfficePro 4, у складі яких програми для створення тестів, проведення тестування й аналізу результатів тестування. За допомогою програми tMaker створюються тести та проводиться їхнє редагування. Тестування проводять 3 використанням програми tTester, а оброблення результатів тестування учнів - за допомогою програми tAdmin.

Такий вид контролю ми інтегруємо 3 усною відповіддю студента під час складання семестрового екзамену з методики навчання української мови. За годину пропонується виконати 150 тестів з вибором одноелементних відповідей (множинний варіант - єдина відповідь), наприклад:

-Які принщипи покладено в основу чинної шкільної програми для початкової школи з української мови:

a) лінійний;

б) особистісної орієнтацій;

в) спіралевидний;

г) взаємозв'язку навчання, виховання й розвитку.

- Про який етап роботи над текстом вірша Я. Щоголіва «Осінь» (3 клас) йдеться: "Які почуття викликав у вас ией опис осені? Як ви гадаєте, ранню чи пізню осінь описує поет?»:

а) підготовчий;

б) первинний аналіз;

в) виявлення емочійного сприймання;

2) творча робота.

- Яким способом пояснимо учням значення слова верховіття:

а) показ предмета чи його зображення;

б) використання контексту;

в) найпростіший словотвірний аналіз;

2) тлумачення слів.

Після завершення тестування студент має можливість довідатися про результати контролю - він може побачити їх на моніторі комп'ютера у вигляді відсоткового відношення правильних і неправильних відповідей або загальної кількості балів.

Перевагами комп'ютерної програми SunRav TestOfficePro 4 для організації моніторингу якості професійних знань учнів $є$ : здійснення тестування не лише з метою вияву рівня професійних знань студентів, але й 3 навчальною метою, що дає можливість виконати одне з головних завдань моніторингу: діагностику й корекцію якості знань; забезпечення студентів можливістю самостійно здійснювати діагностику знань; забезпечення можливості уникнення підробки результатів тестування студентами, захисту тесту від перегляду правильних відповідей; можливість змішувати питання в тесті; установлення часових параметрів для проведення тестування, а також для відповідей на кожне запитання.

Здійснення контролю професійних знань за допомогою програмного забезпечення ASSIST-II (Асистент-II), SunRav TestOfficePro 4 підвищує рівень самостійності студентів в оволодінні знаннями, навичками методики та техніки самостійної роботи; активізує освітній процес; удосконалює навички роботи з персональним комп'ютером. Правильно організована система контролю знань 3 використанням інформаційних технологій забезпечує можливість керування процесом навчання відповідно до принципів зворотного зв'язку та діяльнісного підходу, характеризується об'єктивністю, відсутністю упередженості.

Отже, комп'ютерне тестування - це лише елемент добре організованого й технологічно продуманого освітнього процесу. Якщо студенти матимуть міцні знання, то їх оцінювання не становитиме особливих труднощів, у якій би формі воно не проводилось. 
Ефективно працює в освітньому процесі закладів вищої освіти Google Classroom безкоштовний вебсервіс, укладений Google для закладів освіти з метою створення, поширення і класифікації завдань безпаперовим шляхом. Основна мета сервісу прискорити процес обміну файлами між викладачами і студентами. Студенти можуть бути запрошені до класу через приватний код чи автоматично імпортуватися з сайту вишу. Кожна група створює окрему папку на Google диску відповідного користувача Google Drive, куди студент може подати роботу, щоб викладач іï оцінив. Мобільні додатки, доступні на iOS i Android, дають можливість користувачам робити фото та прикріпляти їх до завдань, ділитися файлами з інших додатків та мати онлайн доступ до інформації. Викладач відстежує прогрес кожного студента, а після перевірки роботу повертає разом з коментарями.

Кількість інформації у світі постійно зростає, тому виникає необхідність уміти ії швидко опрацьовувати й запам'ятовувати. Одним 3 таких ефективних способів $\epsilon$ технологія майндмеппінгу. Вона заснована на зображенні асоціативних зв'язків (складання ментальних карт: карт пам'яті, інтелект-карт, карт розуму, карт мислення) для поєднання візуалізації навчального матеріалу з його «стисненням». Суть побудови ментальної карти полягає в тому, щоб за допомогою зрозумілих символів, образів, об’єктів, асоціацій, якими мислить людина, наочно зобразити карту знань на обрану тему. Ментальні карти - це зручний інструмент для відображення процесу мислення й структуризації інформації у візуальній формі. Ментальні карти дають можливість так оформити інформацію, що мозок легко іiї сприйме, бо інформація записана «мовою мозку». Ментальні карти відображають природний спосіб мислення людського мозку. Якщо ви хочете сприйняти яку-небудь інформацію і для цього оформляєте її у вигляді таблиць, списків, звичайного тексту, то вашому мозку потрібно буде зробити додаткову роботу для перекладу цієї інформації зрозумілою для нього мовою. Якщо ж ця інформація оформлена у вигляді ментальних карт, то вона легко й просто запам'ятається [1, с. 14-15].

Ментальні карти представлясмо у вигляді діаграми, на якій зображені слова, ідеї, завдання або інші поняття, які пов'язані між собою ключовим поняттям. В основі створення - принцип «радіального мислення», що належить до асоціативних розумових процесів, відправною точкою або точкою дотику яких $є$ центральний об'єкт. За допомогою складених за певними правилами карт можна створювати, візуалізувати, структурувати і класифікувати ідеї та наочно представляти досить складні концепції і великі обсяги інформації. Вони охоплюють і допомагають записати, запам'ятати, з'єднати і вивести інформацію візуально. Створюються вони на папері або ж за допомогою програмного забезпечення, якого нині існує вже понад 50 видів. Основні елементи карти - ключі (або їх ще називають тригери): слова й малюнки, кожен 3 яких символізує конкретний спогад, сприяє виникненню нових думок та ідей, а отже, допомагає повніше використовувати можливості розуму. Тригери радіально розходяться від центральної ідеї за допомогою серії з’єднуювальних гілок. Процес побудови карти імітує поведінку нейронів у процесі думання, коли активуються зв'язки між ними [17]. Залежно від обсягу існують програми для створення інтелектуальних карт: bubbl.us, mindmeister, coggle, wise mapping, Freemind, MindNode, mapul, Mindomo, mind42.com, Xmind. Наприклад, на рис. 2 зображено карту, створену в програмі bubbl.us. Однією з основних переваг програми є іï підтримка і сумісність 3 пакетом Microsoft Office та можливість створеної схеми легко масштабуватися i рухатися екраном. 


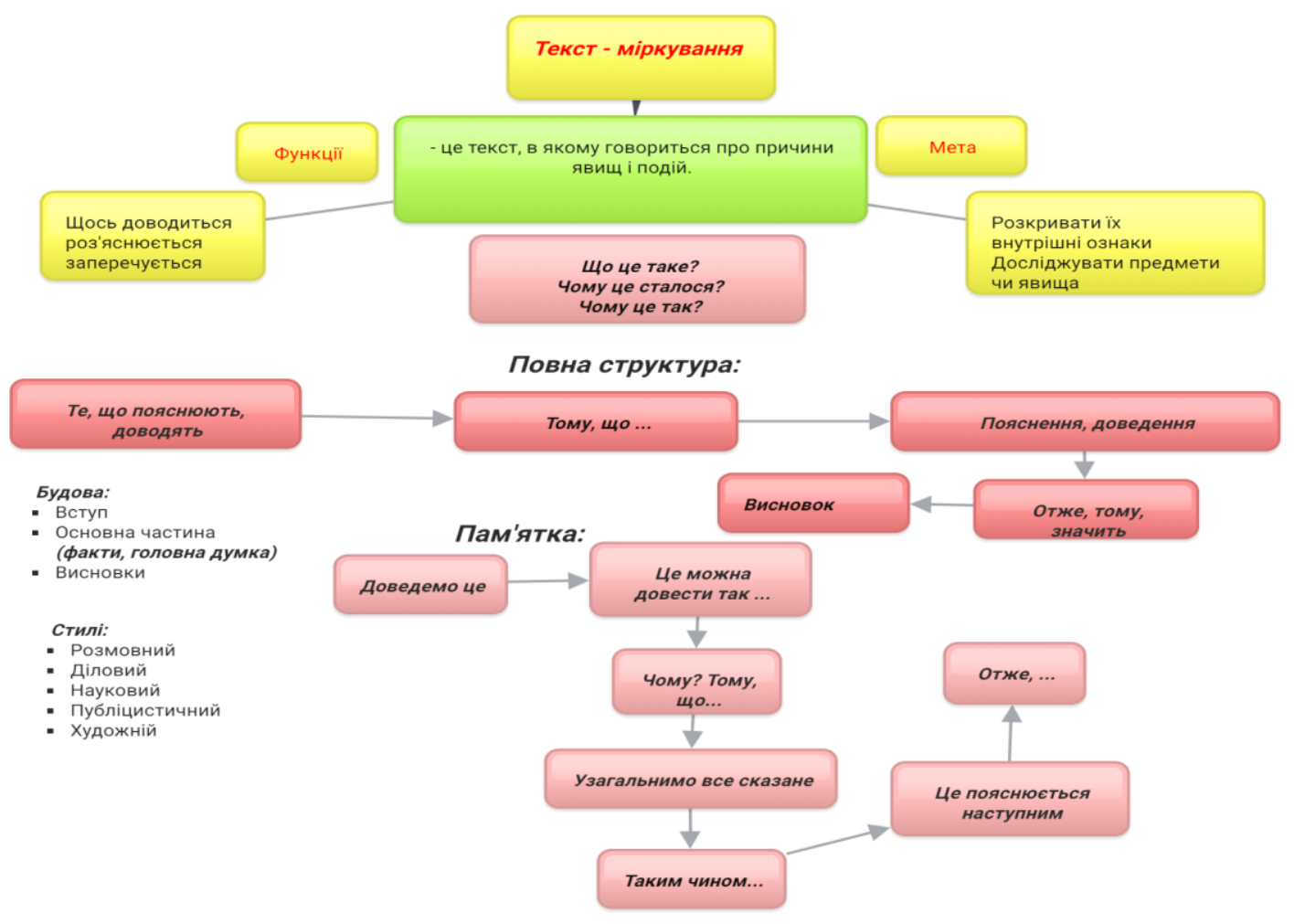

Рис.2. Ментальна карта «Текст-міркування»

\section{3. ВИСНОВКИ ТА ПЕРСПЕКТИВИ ПОДАЛЬШИХ ДОСЛІДЖЕНЬ}

Отже, наявність ІКТ актуалізує проблему підготовки кваліфікованих фахівців, здатних ефективно вирішувати професійні завдання в сучасному інформаційному просторі, а також зумовлює постійне оновлення системи підготовки студентів у вищій школі. ІКТ стають типовим явищем освітянської практики, а готовність до професійної діяльності в інноваційному освітньому середовищі - вимогою до всіх педагогів. Це формує соціальне замовлення на нові підходи в системі освіти, нове ставлення педагога до своєї діяльності. 3 огляду на це основним напрямом освітнього процесу закладів вищої освіти стає підготовка майбутніх учителів до професійної діяльності в інноваційному освітньому середовищі, котрі здатні творчо мислити, працювати 3 суспільством та в суспільстві, сприяти мобільності й креативності.

Тож у ході формування лінгводидактичної компетентності майбутнього фахівця IКТ 3 їх можливістю використання звуку та анімації, різноманітних прийомів візуалізації дають можливість якісно унаочнити освітній процес, індивідуалізувати, отримати швидкий доступ до інформаційних джерел, здійснити реальну комунікацію 3 носіями мови. Поряд із значною інтенсифікацією підготовки вчителя для початкової школи ІКТ уможливлює оперативно, достовірно й об'єктивно провести опитування та оцінити досягнення здобувачів освіти.

Інтерактивні моделі за допомогою технології майндмеппінгу передбачають підготовку майбутнього фахівця на якісно новому рівні. Адже сучасні здобувачі освіти ефективно й активно сприймають інформацію під час використання IКT. Така організація підготовки стимулює самостійну продуктивну працю студентів з великими обсягами інформації. 
Різноманітні програмні продукти для вивчення сучасної української мови, методики навчання української мови дають можливість інтенсифікувати засвоєння навчального матеріалу, підвищити рівень розвитку психологічних механізмів (уяви, пам'яті, уваги), активізувати розумові процеси.

Сучасний освітній процес потребує активних форм навчання. У контексті новітніх вимог випускники закладів вищої освіти мають оволодіти грунтовними теоретичними знаннями, виробити стійкі вміння і навички, набути творчих якостей, удосконалити критичне мислення, сформувати ціннісне ставлення до майбутньої професійної діяльності, здатність до продуктивної комунікації. Таке усвідомлення породжує значну кількість практичних кроків щодо втілення нових підходів до оптимізації різних форм освітнього процесу, що становлять значний дослідницький інтерес, вартий подальшого вивчення.

\section{СПИСОК ВИКОРИСТАНИХ ДЖЕРЕЛ}

[1] Експрес-порадник учителя НУШ: короткий термінологічний словник. уклад. М. М. Греб, Н. В. Грона. Ніжин, Україна: НДУ ім. М. Гоголя, 2019. 48 с.

[2] О. П. Буйницька. Використання електронних навчально-методичних комплексів у процесі фахової підготовки студентів. №5 (25). 2011. С. $42-50$

[3] В. Ю. Биков. Моделі організаційних систем відкритої освіти : монографія. Київ: Атака, 2008. 684c.

[4] О. А. Іщенко. Передумови і проблеми застосування нових інформаційних технологій під час викладання соціально-гуманітарних дисциплін. Освіта. Технікуми. Коледжі. № 1. с. 10-12. 2002.

[5] О. А. Комар. Підготовка майбутніх учителів початкової школи до застосування інтерактивних технологій. Теоретико-методичні аспекти: монографія. Умань, Україна: РВЦ «Софія», 2008. 332 с.

[6] О. А. Копусь. Теоретичні засади формування фахової лінгводидактичної компетентності майбутніх магістрів-філологів у вищому навчальному закладі: монографія. Одеса, Україна, 2012. 429 с.

[7] В. П. Поляков. Архитектоника информационной подготовки специалистов в системе высшего профессионального образования. Учёные зап. Ин-та информатизаиии образования Рос. акад. образования. Вып.16. Москва: ИИО РАО, 2005. с. 115-121

[8] С. В. Хоменко. Методика формування економічних знань у майбутніх інженерів-педагогів засобами комп’ютерних технологій: дис. ... канд. пед. наук : 13.00.02. Харків, 2008. 338 с.

[9] V. Brazdeikis. The educators' competence of applying the information and communication technologies and its evaluation strategies. Summary of dissertation. Kaunas. URL: http://formamente.guideassociation.org/wpcontent/uploads/2008_3_4_Palmira_Juceviciene.pdf. Дата звернення:16.04.2019.

[10] E-Skills for the 21st Century: Fostering Competitiveness, Growth and Jobs (September 2007). European Ecompetence Framework. Version 2.0. September 2010. URL: www.ecompetences.eu. Дата звернення:19.05.2019.

[11] International Society for Technology in Education. Educational Computing and Technology Standards for Technology Facilitation, Technology Leadership and Secondary Computer Science Education (2002). URL: http://cnets.iste.org (дата звернення:26.05.2019).

[12] С. М. Прохорова. Поняття цифрової компетентності вчителя іноземної мови у світовому освітньому просторі. Вісник Житомирського державного університету. Педагогічні науки. Випуск 4 (82), 2015. C.114.

[13] Н. М. Остапенко Теорія і практика формування лінгводидактичних компетентностей у студентів філологічних факультетів ВНЗ. Черкаси: видавець Чабаненко Ю. 2008. 330 с.

[14] В. П. Студенікіна Розвиток методичної компетентності вчителів української мови в системі підвищення кваліфікації: автореф. дис. ... канд. пед. наук: 13.00.04. К. 2013. 20 с.

[15] О. М. Семеног. Професійна підготовка майбугніх учителів української мови і літератури: монографія. Суми, Україна: ВВП «Мрія-1», 2005. 404 с.

[16] I. А. Хижняк. Складники інформаційно-комунікаційного конструкта лінгводидактичної компетентності майбугнього вчителя. Вісник Луганського наиіонального університету імені Тараса Шевченка. Педагогічні науки. № 11, Ч. 2. с. 166-172. 2012.

[17] В. И. Владимирова. Компетентностно ориентированное обучение в высшей школе. Актуальні проблеми лінгвістики, професійної лінгводидактики, психології і педагогіки вищої иколи: зб. статей II Всеукраїнської наук.-практ. конф. з міжнародною участю (8-9 червня 2017 р.). Полтава, Україна: Астрая. с. 33-36. 2017. 
[18] О. А. Кучерук. Методологічні засади особистісно орієнтованої лінгводидактики. Укр. мова $і$ літ-ра $в$ школі. № 6. с. 20-24. 2013.

[19] О.А Кучерук., С. О. Караман, О. В. Караман,, Н. М. Віннікова. Використання ІКТ для формування фахових компетентностей у майбутніх учителів української мови і літератури. Інформаційні технології і засоби навчання, 2019, Том 71. №3. URL: https://journal.iitta.gov.ua/index.php/itlt/article/view/2814/1496

[20] М. М. Левшин. Інформаційні технології - з першого класу. Вища освіта Украйни. № 1. с. 58-64. 2002.

[21] Р. С. Гуревич. Інформаційно-телекомунікаційні технології в навчальному процесі та наукових дослідженнях: навч. посіб. для студ. пед. ВНЗ і слухачів інститутів післядипломної освіти. Київ, Україна: «Освіта України». 2006. 390 с.

Матеріал надійшов до редакиії 08.07.2019 p.

\title{
ИНФОРМАЦИОННО-КОММУНИКАЦИОННЫЕ ТЕХНОЛОГИИ КАК СРЕДСТВО ФОРМИРОВАНИЯ ЛИНГВОДИДАКТИЧЕСКОЙ КОМПЕТЕНТНОСТИ БУДУЩИХ УЧИТЕЛЕЙ НАЧАЛЬНЫХ КЛАССОВ
}

\section{Греб Мария Михайловна}

доктор педагогических наук, доцент,

заведующая кафедрой украинского языка и славистики,

Бердянский государственный педагогический университет, г. Бердянск, Украина

ORCID ID 0000-0003-2874-7985

marygreb@i.ua

\section{Грона Наталия Викторовна}

доктор педагогических наук, преподаватель высшей категории, преподаватель-методист, председатель цикловой комиссии преподавателей украинского языка и литературы Прилуцкий гуманитарно-педагогический колледж им. И Я. Франко, г. Прилуки, Украина ORCID ID 0000-0003-2578-2865

natashagrona@ukr.net

\begin{abstract}
Аннотация. В статье исследована специфика применения информационнокоммуникационных технологий в процессе формирования лингводидактической компетентности будущих учителей начальных классов. Теоретически обосновано и показано на конкретных примерах эффективность формирования лингводидактической компетентности будущих учителей начальных классов средствами информационнокоммуникационных технологий. Авторы доказывают, что применение ИКТ улучшает восприятие, осмысление и запоминание учебной информации, помагает осуществить дифференцированный подход к обучению студентов и положительно влияет на их мотивацию к учебной деятельности.

Проанализировано содержание лингводидактической подготовки будущего учителя начальных классов, которая связана с профессиональной полифункциональностью, многопредметностью, разветвленностью художественно-творческой и эмоциональнокоммуникативной сферы взаимодействия с учащимися, высоким уровнем диалогичности и референтности в отношениях с ними, духовно-нравственной насыщенностью содержания образования.

Акцентировано на том, что достижения в лингвистике влияют не только на содержание обучения языку, но и на приемы работы, виды упражнений, дидактический материал и тому подобное. Это приводит к постоянному обновлению системы лингводидактической подготовки студентов в высшей школе в соответствии с инновационными аспектами развития образовательного пространства, совершенствует условия создания, сохранения и обеспечения оптимальных способов представления информации средствами информационно-коммуникационных технологий.

Сформулированы рекомендации будущим специалистам по созданию презентаций. Осуществлен анализ внедрения и использования компьютерных тестов (в компьютерной программе тестирования ASSIST-II (Ассистент-II). Такая форма, как правило, вызывает дополнительный интерес у студентов, а кроме того, позволяет им самостоятельно без
\end{abstract}


участия преподавателя проверить и оценить уровень собственных знаний по конкретной теме (модулю).

Описана технология майндмэппинга, которая основана на изображении ассоциативных связей (составление ментальных карт: карт памяти, интеллект-карт, карт ума, карт мышления) и сочетает визуализацию учебного материала с его «сжатием».

Проанализированы возможности и преимущества каждой ИКТ при формировании лингводидактической компетентности будущего учителя начальных классов.

Ключевые слова: лингводидактическая компетентность; учитель начальных классов; информационно-коммуникационные технология; презентация; компьютерное тестирование; мобильные приложения; технология майндмэппинга.

\title{
INFORMATION AND COMMUNICATION TECHNOLOGIES AS A MEANS OF FORMING LINGUODIDACTIC COMPETENCE OF FUTURE PRIMARY SCHOOL TEACHERS
}

\author{
Mariia M. Hreb \\ Doctor of Pedagogical Sciences, Professor, Head of the Department of Ukrainian Language and Slavic Studies \\ Berdyansk State Pedagogical University, Berdyansk, Ukraine, \\ ORCID.ID 0000-0003-2578-2865 \\ marygreb@i.ua

\section{Nataliia V. Hrona} \\ Doctor of Pedagogical Sciences, Teacher of Higher Category, Teacher-methodologist, Chairman of the Cycle \\ Commission of Teachers of the Ukrainian language and literature at Prylutck Humanitarian and Pedagogical \\ College named after I. Ya. Franko, Pryluky, Ukraine, \\ ORCID.ID 0000-0003-2578-2865 \\ natashagrona@ukr.net
}

\begin{abstract}
The article studies the specifics of the use of information and communication technologies in the process of forming linguodidactic competence of future primary school teachers. It is theoretically substantiated and shown by definite examples the effectiveness of forming linguodidactic competence of future primary school teachers by means of information and communication technologies. The authors argue that the use of ICT will improve the perception, understanding and memorization of learning information, help differentiate students' learning and have a positive effect on their motivation for learning.

The content of linguodidactic preparation of a future primary school teacher, which is connected with professional polyfunctionality, multidisciplinary nature, branching of artistic, creative and emotional-communicative sphere of interaction with students, high level of dialogue and reference in education, is analyzed.

It is emphasized that the achievements in linguistics affect not only the content of language learning, but also the methods of work, types of exercises, didactic material, etc. It causes constant updating of the system of linguodidactic preparation of students in higher education in accordance with innovative aspects of development of educational space, improves the conditions of creation, preservation and provision of optimal ways of presenting information by means of information and communication technologies.

Recommendations for future specialists to create a presentation are formulated. The analysis of the implementation and use of computer tests (in the computer testing program ASSIST-II) is performed. This form, as a rule, is of an additional interest to students, and, besides, allows them to test and evaluate their own knowledge of a specific topic (module) independently without the participation of the teacher.

Mindmapping technology, which is based on the image of associative relationships (mental maps: memory cards, intelligence cards, mind maps, thinking cards) is described and combines visualization of training material with its "compression".

Possibilities and advantages of each ICT in the formation of the linguistic competence of a future primary school teacher are analyzed.
\end{abstract}

Keywords: linguodidactic competence; primary school teacher; information and communication technologies; presentation; computer testing; mobile applications; technology of mindmapping. 


\section{REFERENCES (TRANSLATED AND TRANSLITERATED)}

[1] The Express-Reference-Book of the Teacher of New Ukrainian School: the Short Terminological Dictionary. Ukl. M. M. Hreb, N. V. Hrona. Nizhyn: NDU im. M. Hoholya. 48 p. 2019. (in Ukrainian).

[2] O. P. Buinytska. Use of electronic educational-methodical complexes in the process of professional preparation of students. no. 5 (25). 2011. [Online]. Available: http://www.journal.iitta.gov.ua. (in Ukrainian).

[3] V. Yu. Bykov. Models of Organizational Systems of Open Education: monograph. Kyiv: Attack, 684 p. 2008. (in Ukrainian).

[4] O. A. Ishchenko. Prerequisites and problems of the application of new information technologies in the teaching of social and humanitarian disciplines. Education. Technical schools. Colleges no. 1. pp. 10-12. 2002. (in Ukrainian).

[5] O. A. Komar. Preparation of future teachers of elementary school to the use of interactive technologies. Theoretical and methodical aspects: monograph. Uman: RVC «Sofia», 332 p. 2008. (in Ukrainian).

[6] O. A. Kopus. Theoretical principles of formation of professional linguistic and pedagogical competence of future masters-philologists in higher educational institutions: monograph. Odessa, 429 p. 2012. (in Ukrainian).

[7] V. P. Poliakov. Architectonics of information training of specialists in the system of higher professional education. Scientific notes of the Institute of Informatization of Education of the Russian Academy of Education. Issue 16. Moscow: AIE RAO, 2005. (in Russian).

[8] S. V. Khomenko. Methodology of formation of economic knowledge of future engineers-teachers by means of computer technologies: dissertation of Methodology of formation of economic knowledge of future engineersteachers by means of computer technologies: dissertation of the candidate of pedagogical sciences: 13.00.02: 13.00.02. Kharkiv, 338 p. 2008. (in Ukrainian).

[9] V. Brazdeikis. The educators' competence of applying the information and communication technologies and its evaluation strategies. Summary of dissertation. Kaunas. [Online]. Available: http://formamente.guideassociation.org/wp-content/uploads/2008_3_4_Palmira_Juceviciene.pdf. (in English).

[10] E-Skills for the 21st Century: Fostering Competitiveness, Growth and Jobs (September 2007). European Ecompetence Framework. Version 2.0. [Online]. Available: www.ecompetences.eu. (in English).

[11] International Society for Technology in Education. Educational Computing and Technology Standards for Technology Facilitation, Technology Leadership and Secondary Computer Science Education (2002). [Online]. Available: http://cnets.iste.org. (in English).

[12] S. M. Prokhorova. The concept of digital competence of a foreign language teacher in a global educational space. Bulletin of Zhytomyr State University. Pedagogical Sciences. Issue 4 (82), 2015. 114p.. (in Ukrainian).

[13] N. M. Ostapenko Theory and practice of formation of linguo-didactic competences in students of philological faculties of universities. Cherkasy: Publisher Chabanenko Yu. 2008. 330p. (in Ukrainian).

[14] V. P. Studenikina Development of methodological competence of Ukrainian language teachers in the system of professional development: author. diss. ... Cand. ped. Sciences: 13.00.04. 2013. 20p. (in Ukrainian).

[15] O. M. Semenog. Professional training of future teachers of the Ukrainian language and literature: monograph. Sum: GDP «Mriya-1», 404 p. 2005. (in Ukrainian).

[16] I. A. Khizhnyak. The Components of the Information and Communication Design of the Lingvodidactic Competence of the Future Teacher. Herald of Taras Shevchenko National University of Lugansk. Pedagogical sciences. No. 11, Ch. 2. pp. 166-172. 2012. (in Ukrainian).

[17] V. I. Vladimirova. Competency-Oriented Education in Higher School. Actual problems of linguistics, professional lingvodidactics, psychology and pedagogics of higher education: a collection of articles of the II All-Ukrainian scientific and practical conference with international participation (June 8-9, 2017). Poltava: Astraya, pp. 33-36. 2017. (in Russian).

[18] O. A. Kucheruk. Methodological principles of personally oriented linguodidactics. Ukrainian language and literature at school. no. 6. pp. 20-24. 2013. (in Ukrainian).

[19] O.A Kucheruk. S. O. Karaman O. V. Karaman N. M. Vinnikova. The use of ICT for the formation of professional competencies of future teachers of Ukrainian language and literature. Information Technologies and Learning Tools, 2019, vol. 71. no.3. [Online]. Available: https://journal.iitta.gov.ua/index.php/ittl/article/view/2814/1496. (in Ukrainian).

[20] M. M. Levshyn Information technology - from the first class. Higher education in Ukraine. no. 1. pp. 58-64. 2002. (in Ukrainian).

[21] R. S. Hurevych. Information and telecommunication technologies in the educational process and scientific researches: textbook. tool. for students. Pedagogical Universities and students of institutes of postgraduate education. Kyiv, Ukraine: Education of Ukraine. 2006. 390 p. (in Ukrainian).

\section{(cc) BY-NC-SA}

ThisworkislicensedunderCreativeCommonsAttribution-NonCommercial-ShareAlike 4.0 InternationalLicense. 